\title{
THE LODGE CASE AND THE MisAPPLiCATION OF THE PER SE CARTEL PROVISIONS OF THE COMMERCE ACT 1986
}

\author{
Edward Willis*
}

\begin{abstract}
An arrangement to fix, control or maintain prices is the classic competition law per se offence, and is deemed to substantially lessen competition under s 30 of the Commerce Act 1986. However, it is currently unclear when arrangements that do not explicitly concern price fall within the ambit of $s$ 30. This article examines the recent Court of Appeal decision in Commerce Commission v Lodge Real Estate Ltd which found that the defendants were liable under the per se offence provisions. ${ }^{1}$ It contends that the Court of Appeal took the overseas case law out of context, misunderstood key factual findings made by the High Court at first instance and overlooked important legal and policy considerations. As a result it is argued that Lodge sets an unfortunate precedent that should be overruled or strictly confined to its own facts.
\end{abstract}

\section{INTRODUCTION}

It was a challenging period for real estate agencies operating in the Hamilton market in 2013. Prior to that time, it was common practice among real estate agencies to advertise listings on a popular Internet-based marketplace, trademe.co.nz (Trade Me). This practice was initially cost-effective because Trade Me charged a flat monthly rate to each agency. That changed when Trade Me notified the agencies that it would alter its fee structure, with a separate charge applying in respect of each listing.

This potential cost shock was of considerable concern to all real estate agencies in the Hamilton area. It resulted in a meeting of representatives of a number of those agencies where the issue could be discussed. By all accounts, the purpose of the meeting was to ascertain the viability of a jointly

* Lecturer, Faculty of Law, University of Auckland. Thanks to Robert Bycroft, An Hertogen, James Mellsop and an anonymous peer reviewer for helpful feedback on earlier drafts.

1 Commerce Commission v Lodge Real Estate Ltd [2018] NZCA 523 [Lodge (CA)]. 
operated online alternative to Trade Me, realestate.co.nz. However, discussions at the meeting turned to the increased costs themselves and several representatives allegedly commented that their respective agencies simply could not absorb the cost increase. The obvious solution was that the real estate agencies' clients, the individual vendors in respect of each listing, would need to contribute to the increased cost in some way.

The Commerce Commission took exception to the meeting, and the real estate agencies involved. The Commission reasoned that the representatives at the meeting had agreed on the co-ordinated treatment of a significant input cost, and as a result price competition among the agencies for real estate services would be distorted. Accordingly, the Commission alleged, the agencies had breached the prohibition in the Commerce Act 1986 (the Act) against co-ordinated behaviour with the purpose or effect of substantially lessening competition in any market. ${ }^{2}$ In particular the Commission alleged a breach by way of s 30 of the Act, which at the relevant time deemed there to be a substantial lessening of competition where there is "a contract, arrangement, or understanding" that "has the purpose, or has or is likely to have the effect of fixing, controlling, or maintaining ... the price for goods or services" supplied by the parties in competition with each other. ${ }^{3}$

The agencies defended the charges on a number of grounds. In the High Court, the Commission was successful on every ground save for one crucial exception. Jagose $J$ found that while an arrangement among the parties had been established, that arrangement related to Trade Me advertising being subject to a vendor funding model. ${ }^{4}$ His Honour noted that "vendor funding" is not a term of art with a clearly accepted meaning, and the Commission could not demonstrate that reliance on that term required or implied any specific treatment of the costs associated with Trade Me advertising in respect of specific transactions. ${ }^{5}$ While in general it appears that in practice these costs would often be passed on to the vendor directly as a separately invoiced item, this was not necessarily the case and it remained a matter for each agency to determine the final treatment of those costs in individual circumstances in light of the prevailing market conditions. ${ }^{6}$ There was, therefore, a crucial gap in the Commission's theory of the case: the agreed vendor funding model was so broad that the arrangement did not and could not constrain the final prices of the agencies' services to their vendor clients as required by s 30 .

2 Commerce Act 1986, s 27.

3 Section 30 (repealed by s 8 of the Commerce (Cartels and Other Matters) Amendment Act 2017).

4 Commerce Commission v Lodge Real Estate Ltd [2017] NZHC 1497 [Lodge (HC)] at [227].

5 At [231]

6 At [227]-[228]. 
The Commission appealed. In a unanimous judgment the Court of Appeal disregarded the High Court's findings of fact in relation to the nature and effect of the arrangement. ${ }^{7}$ Instead, it insisted that any arrangement relating to the potential treatment of an input cost would necessarily have an effect on the end price of services offered. While the Court purported to find some support for this position in the overseas case law, the reasoning is sparse and primarily turns on rhetorical appeals to matters that must "obviously" or "plainly" be the case. This article offers a critical examination of the Court of Appeal's decision on this crucial point. It argues that the overseas case law cited by the Court does not in fact support the Court's analysis, that the Court's overruling of the High Court's initial findings appears to be based on a misunderstanding of the key facts, and that the Court's reluctance to engage in close analysis of the issues cannot be supported on legal or policy grounds. Accordingly, it is doubtful whether the Court of Appeal's judgment on this point can credibly stand.

The issue of when per se liability attaches is of particular moment given the strong likelihood that per se conduct will soon be subject to criminal sanctions. ${ }^{8}$ This raises the stakes immensely for competition law analysis generally and defendant businesses in particular. If per se liability is then able to be invoked in inappropriate cases, the Commission may avoid the need to demonstrate its case to the usual evidential standard, resulting in undesirable prosecutions. Per se liability under the Act is intended to apply only to the particular harm of artificial constraints on market-determined pricing (or to output restrictions or market allocation under the amended law). Extending the scope of per se liability beyond this specifically identified conduct therefore undermines the sound legal functioning of New Zealand's competition law regime.

This article's argument proceeds in the following way. Following this introduction, Part II offers a brief summary of the relevant legislative provisions, noting in particular that s 30 applies only in respect of conduct that impacts on the competitive setting of prices. Part III then sets out the decision of the High Court, which found that the necessary connection between the impugned conduct and price effects was not demonstrated on the available evidence. The analysis in this part both provides context to, and serves as a counterpoint for, the decision of the Court of Appeal. Part IV examines the Court of Appeal's decision. The Court's willingness to assume liability in the absence of close scrutiny of the underlying facts is challenged in three ways. First, the overseas case law cited by the Court in support of its approach in fact requires close scrutiny of the factual evidence. Second, a superficial account of the facts led to the Court to misinterpret the approach of the High Court, which was certainly valid on the basis of the available evidence. Third, the Court appears to have misunderstood the policy grounds supporting per se liability under s 30. Part V offers a brief conclusion that discusses the ramifications of the Court of Appeal's analysis in Lodge and argues that if it is not overturned on appeal its precedent value should be narrowly confined.

7 Lodge (CA), above n 1.

8 Commerce (Criminalisation of Cartels) Amendment Bill 2018 (22-2). 


\section{STATUTORY CONTEXT}

The Commerce Act is New Zealand's principal competition law statute. Like other competition law statutes in modern democracies the Act controls merger activity in concentrated markets, ${ }^{9}$ prohibits unilateral conduct that risks market foreclosure, ${ }^{10}$ and (most relevantly for this article) prohibits co-ordinated conduct that results in a meaningful reduction in competitive tension among market participants. In relation to anti-competitive co-ordinated conduct, s 27(1) of the Commerce Act provides:

\footnotetext{
No person shall enter into a contract or arrangement, or arrive at an understanding, containing a provision that has the purpose, or has or is likely to have the effect, of substantially lessening competition in a market.
}

Section 27(2) prohibits giving effect to any such contract, arrangement or understanding in similar terms. In standard competition law parlance, these provisions engage an "effects-based" analysis. Co-ordinated conduct is only prohibited if the conduct has the purpose or (likely) effect of a material reduction in-market competition. If the Commission alleges a breach of s 27 , it is usually required to demonstrate on the balance of probabilities the anti-competitive impact on one or more markets of the impugned conduct.

However, the burden of demonstrating in-market anti-competitive effects can be avoided if the impugned conduct comes within the terms of s 30 of the Act. At the time of the real estate agencies' meeting, s 30(1) of the Act provided as follows: ${ }^{11}$

Without limiting the generality of section 27, a provision of a contract, arrangement, or understanding shall be deemed for the purposes of that section to have the purpose, or to have or to be likely to have the effect, of substantially lessening competition in a market if the provision has the purpose, or has or is likely to have the effect of fixing, controlling, or maintaining, or providing for the fixing, controlling, or maintaining, of the price for goods or services, or any discount, allowance, rebate, or credit in relation to goods or services, that are-

(a) supplied or acquired by the parties to the contract, arrangement, or understanding, or by any of them, or by any bodies corporate that are interconnected with any of them, in competition with each other; or

(b) resupplied by persons to whom the goods are supplied by the parties to the contract, arrangement, or understanding, or by any of them, or by any bodies corporate that are interconnected with any of them in competition with each other.

9 Section 47

10 Section 36.

11 Section 30 of the Act was repealed by the Commerce (Cartels and Other Matters) Amendment Act. 
Section 30 is a deeming provision. Any contract, arrangement or understanding between or among competitors that has the purpose, effect or likely effect of "fixing, controlling, or maintaining" the price for goods or services acquired by those competitors will automatically result in a breach of the prohibition in s 27 without the need to conduct an effects-based analysis. To invoke the standard competition law parlance for a second time, s 30(1) creates a per se offence. The underlying policy of per se offences of this nature is that the probability of harm to competition (usually by increasing prices above competitive levels) is very high, while the likelihood of the conduct producing countervailing benefits is extremely low. ${ }^{12}$ The additional cost involved in proving an anti-competitive purpose or effect is disproportionate to the serious harm of interference with market pricing disciplines. Once a provision with the purpose or effect of fixing prices among competitors is established, a contravention of the s 27 prohibition will necessarily follow. ${ }^{13}$

A breach of s 27 of the Commerce Act by way of s 30 may seem straightforward when put in those terms, but a key issue remains concerning the circumstances in which s 30 applies. On the plain wording of the section, there must be an arrangement with an actual or intended impact on final prices for goods and services. This will almost certainly be the case where the subject matter of the arrangement itself is to directly control the level of final output prices, which is the classic example of price-fixing. In addition, arrangements that restrict levels of output or allocate markets among competitors will usually engage s 30 , as it is accepted as a basic principle of competition law economics that such arrangements raise final prices by restricting supply relative to demand. ${ }^{14}$ In other words, although output restrictions and market allocation arrangements are not specifically prohibited by s 30 in plain terms, such restrictions will often have the purpose or (likely) effect of fixing, maintaining or controlling the prices for goods or services. The entire impetus for a s 30 inquiry is to determine whether prices are (or because of the arrangement are not) set by competitive market processes. ${ }^{15}$ Output restriction and market allocation arrangements are, therefore, caught by s 30 provided that the link between the agreed restriction and an effect on final prices can be established.

Some analysis of pricing effects is therefore a necessary component of bringing competitor arrangements within s 30 where final output prices are not themselves the subject of the arrangement. This may strike those unfamiliar with New Zealand competition law as a slightly odd result. Section

12 Chris Noonan Competition Law in New Zealand (Thomson Reuters, Wellington, 2017) at 356.

13 Commerce Commission v Taylor Preston Ltd [1998] 3 NZLR 498 (HC) at 504. It is not controversial that each of the three possible forms of price-fixing referred to in s 30(1) - purpose, effect or likely effect - produce an equivalent contravention of s 27.

14 See Paul Scott "Unresolved Issues in Price Fixing: Market Division, the Meaning of Control and Characterisation" (2006) 12 Canta LR 197. The Commerce (Cartels and Other Matters) Amendment Act now makes the law on this point explicit.

15 Miriam R Dean "Collective pricing - A practical guide to section 30 of the Commerce Act 1986" (1990) 20 VUWLR 1 at 2. 
30 establishes a per se offence which deliberately eases the evidential burden for the prosecution by avoiding the need for analysis of in-market competition effects, but may then erect a secondary evidential barrier to successful prosecution by requiring analysis of pricing effects in certain circumstances. Any apparent inconsistency is no more than superficial. The per se nature of the offence relates only to the purpose or (likely) effect of substantially reducing competition as set out in s 27, and so the prosecution is still burdened with the need for an "effects" analysis in relation to final prices. This much is clear on the plain language of $s 30$, but the question of precisely how the link between a competitor arrangement and pricing effects should be established for the purposes of s 30 is left open. As the following analysis demonstrates, the High Court and Court of Appeal in the Lodge case each reached very different answers to this important question.

\section{THE HIGH COURT JUDGMENT}

As foreshadowed in the introduction, the Lodge case concerned a meeting of the representatives of competing real estate agencies in Hamilton. That meeting took place on 30 September 2013. At that meeting a common understanding was allegedly reached in relation to the competitors' preferred treatment of listing fees for use of Trade Me's online platform. The Commission alleged that this constituted an arrangement to control prices in breach of s 27 of the Commerce Act by way of s 30 . The arrangement did not involve any agreement as to the direct control of final output prices for real estate services, however, merely an understanding relating to the treatment of input costs. As a result, for the Commission to be successful the Court needed to be satisfied of the conceptual link between the subject of the arrangement - the listing fee costs - and the target of s 30 - final output prices.

At first instance, the Commission's allegations against the agencies were heard in the High Court by Jagose J. ${ }^{16}$ His Honour delivered an extensively reasoned and careful judgment, necessitated by the number and sophistication of the legal arguments put forward by the agencies to resist the allegations. These included arguments that there had in fact been no contract, arrangement or understanding at all, ${ }^{17}$ that the agencies acted independently of any alleged meeting of the minds and so there had been no mutuality, ${ }^{18}$ that the agencies were not in fact in competition with each other ${ }^{19}$ and that there was no fixing, controlling or maintaining of prices. ${ }^{20}$ The defendant agencies succeeded only in respect of the final argument regarding whether there had been any fixing, controlling or maintaining of prices. That is the issue on which this article focuses.

16 Lodge (HC), above n 4.

17 At [175]-[193].

18 At [194]-[200].

19 At [201]-[208].

20 At [209]-[234]. 
The High Court judgment sets out the facts of the case as determined by his Honour in some detail. At the relevant time the defendant agencies - Lodge Real Estate Ltd, Lugton's Ltd, Monarch Real Estate Ltd (local franchisee of the "Harcourts" national brand), Online Realty Ltd (local franchisee of the "Ray White" national brand) and Success Realty Ltd (local franchisee of the "Bayleys" national brand) - each provided real estate agency services in competition with each other in the Hamilton area. These services included promotion and marketing of properties for sale. Such services are purchased from an agency on a commission basis by home owners who wish to sell their property (the vendors). Any third party costs associated with the promotion and marketing services incurred by the agency are usually passed on to the vendors directly as a separately invoiced item, but the agency or one of its agents might choose to absorb the cost in particular circumstances.

For a number of years, the agencies had made use of the Trade Me online marketplace and classified advertising platform. Initially, Trade Me's services were available to real estate agencies on the basis of a fixed monthly subscription fee of $\$ 999.00$. This was an attractive arrangement for the agencies as it was cost-effective to list large numbers of properties. Lodge, for example, paid to Trade Me around \$9,000 in subscription fees annually under this arrangement, which represented approximately $\$ 6.00$ for each listed residential property. ${ }^{21}$ Unlike with most other third party costs, the usual practice in the market was that the cost of the subscription fee was met by the agency, rather than being separately invoiced to individual vendors.

This arrangement between each of the real estate agencies on the one hand and Trade Me on the other was disrupted in 2013. At that time, Trade Me notified real estate agencies nationwide that it would be changing its fee structure by ending the fixed fee arrangement and replacing it with a fee of $\$ 199.00$ for each individual listing. This was a substantial increase in costs (Lodge's annual fees of around \$9,000 would have increased to around $\$ 300,000$, for instance). In response, representatives of the impugned real estate agencies convened the 30 September meeting. It was generally understood by the participants that the purpose of the meeting was to discuss the changes to Trade Me's fee structure and possible responses to it. $^{22}$

Aside from a single handwritten note made by one of the attendees, the evidence of what actually occurred at the 30 September meeting took the form of oral interviews of attendees conducted by the Commission's investigatory staff after the fact. That evidence indicated that the parties each went into the meeting with the independent view that they could no longer absorb the Trade Me fees. There was some alignment among the representatives that their respective agencies would not be able to continue to meet the new, higher costs into 2014, and the shared sentiment was that listings with Trade Me would probably discontinue by around that time. There was also some discussion about the possibility of advertising listings on a website jointly owned by the respective agencies, realestate.co.nz. This

21 At [47].

22 At [90]-[91]. 
would go some way towards addressing the cost increase Trade Me was imposing, but it was recognised that in reality vendors would sometimes still wish to advertise with Trade Me. To address this issue, the representatives of the agencies noted the inevitability of a move to a vendor funding model. What is not completely clear is whether this treatment of Trade Me fees was implicit in the shared view that it would be unprofitable to absorb the price increase, or whether it was directly discussed and agreed as a shared course of action at the meeting itself (this remains a point of contention between the parties).

The Commission argued that the arrangement discussed at the 30 September meeting constituted a restraint on the competitive setting of the final price for real estate services. ${ }^{23}$ The per se provisions in s 30 were therefore engaged. This was necessarily the case, counsel for the Commission contended, because the arrangement was that the price charged to the vendor by each of the agencies would include the whole of the listing fee charged by Trade Me. The contention was, in effect, that an agreement to adopt a vendor funding model in respect of Trade Me fees meant that the cost would be required to be passed through to the vendor. If that contention could be sufficiently demonstrated with reference to the available facts, that would likely have concluded the matter in the Commission's favour. However, the High Court disagreed with this submission because it was not consistent with the facts of the case as established by the available evidence. The term "vendor funding" simply did not actually carry that meaning. Rather, it meant that Trade Me's listing fees would be treated in the same way as other third party advertising. Usually these costs would be invoiced to the vendor separately by the real estate agency, in line with the standard business practice in the industry, but not always. Where necessary or desirable because of an individual agency's approach or the dictates of the market in respect of a particular transaction, some or all of the third party expenses would be borne by the agency (in the sense that the costs were met by the commission earned if a sale was completed).

This factual finding was particularly relevant because of the legal position his Honour reached. The High Court approached the issue of "fixing, controlling, or maintaining of the price" as having a focus on collusive restraint. ${ }^{24}$ The inclusion of "control" in the list of prohibited activities in relation to price means that it is not necessary that a final price is determined. It is sufficient that a freedom to set price that would otherwise exist has been restrained or interfered with. ${ }^{25}$ On this basis, his Honour was able to conclude as a matter of fact that there was no effective restraint on the competitive setting of the final price. Further, as the arrangement was manifestly ineffective in this regard, influencing

23 At [214].

24 At [209]. A related argument that a de minimis exception applies to s 30 was rejected at [213].

25 At [210], following Australian Competition and Consumer Commission v CC (NSW) Pty Ltd [1999] FCA 954, (1999) 92 FCR 375. 
prices could not have been its objective purpose. ${ }^{26}$ His Honour's conclusion on this point is usefully set out in the following paragraph of the High Court judgment: ${ }^{27}$

By "vendor funding", the agencies meant only some portion of the new cost would be borne collectively by vendors - that is, no agency "was going to company fund it". That is the persistent theme of the evidence from the Commission agency witnesses who attended the 30 September 2013 meeting. It is also [Monarch representative at the meeting] Mr King's evidence, under cross-examination from [Commission counsel] Mr Dixon: "... there can be vendor funding by someone paying a $100 \%$. There can be vendor funding by someone just paying part of it. There can be agent funding." On any individual transaction in the supply of real estate sales services or real estate advertising services, the full range of price setting options remained. The saving of agencies' former Trade Me subscription fees also provided opportunity to access that range on any particular transaction. And it is at that individual level of analysis "price" is to be understood - the "prices at which goods are in fact sold or offered for sale on terms where acceptance will result in a contract": it is not an expansive concept. The arrangement or understanding does not interfere with the competitive setting of price.

This approach by the High Court drew primarily on close analysis of the facts in evidence to try and fully understand any link between the subject matter of the agreement or understanding and any effect of final prices. It makes sense to examine the facts closely in this way, given there appeared to be no case law directly on point before the Court. Further, the Court had determined, after argument from counsel on the point, that economic evidence would not be admitted because of the per se nature of the offence in issue. Cogent analysis of the actual facts was therefore the only avenue remaining for the Court to establish a contravention of s 30 where the alleged arrangement or understanding relates only to input costs.

Much, therefore, turns on the plausibility of this factual finding, and it is possible that the finding be contested. The judgment does refer to evidence that at least some of the participants at the meeting understood that they had "agreed in principle" to only vendor funding for Trade Me listing fees. ${ }^{28}$ Perhaps confusingly, the Court then lent on the same language to describe the effects of the vendor funding model. The term "vendor funding" in this context means treatment of fees comparably with other third party advertising - "in principle, to be paid for by the vendor". ${ }^{29}$ But the wider context of these passages makes clear that the Court was referring to an established commercial practice rather than any agreement as to the pass-through of costs. Indeed, the Court immediately went on to state: ${ }^{30}$

26 Lodge (HC), above n 4, at [234].

27 At [227] (emphasis added, footnotes omitted).

28 At [57].

29 At [215].

30 At [215]. 
But that was not to prevent, in particular necessary or desirable circumstances, the agency and/or the agent bearing some portion or all of that third party expense. Each of the Commission's agency witnesses who attended the 30 September 2013 meeting confirmed that position.

That real estate agencies retained full discretion and vendors would not always pay the Trade Me fees was also confirmed on the factual evidence. In response to a compulsory information request from the Commission: ${ }^{31}$

... Lodge was required to provide "tabulated information for identified listings". Although the precise scope of the Commission's notice was not in evidence, it appeared to require information for 12 listings in February 2014, of which Mr O'Rourke said "Lodge paid the whole of the Trade Me fee for 7 and part of the fee for 1", and 9 listings in August 2014, of which "Lodge paid the whole fee for 5 and part of the fee for $2 "$.

This approach is difficult to square with an agreement in principle to pass through Trade Me fees to vendors. It speaks to a somewhat different interpretation of the available facts: that vendor funding referred to a move away from guaranteed agency funding to treatment determined by commercial judgement and market circumstances. On this interpretation - which was clearly available to the Court - no constraint on final pricing could have been intended or be likely to occur.

It is equally clear that there is room on the basis of this approach of close factual analysis for the Court to have found a relevant connection between an understanding that input costs would be treated in a particular way and a purpose or effect of controlling final output prices. But this relationship cannot be assumed or approached generically. Rather it must be demonstrated on the balance of probabilities on the factual evidence before the Court. In other words, the onus was on counsel for the Commission to demonstrate that the agreement had the effect of fixing, controlling or maintaining the price for real estate agency services. However, the Commission appeared simply to assume that any agreement relating to an input cost would necessarily have such effect without the need to actually address the factual evidence. This was either a shortcoming in the Commission's theory of the case or a remarkable oversight on the part of counsel. In either case, Jagose $\mathrm{J}$ was forced to reach a conclusion that the specific allegations in the case could not be made out on the factual evidence available. Whether or not price fixing had actually occurred at the 30 September meeting, the Commission had simply not made out its case under s $30 .{ }^{32}$

\section{THE COURT OF APPEAL JUDGMENT}

The Commission appealed Jagose J's decision to the Court of Appeal. The defendant agencies also cross-appealed on a number of grounds. In a unanimous judgment delivered by Asher $\mathrm{J}$ (with

31 At [228].

32 This of course does not mean that an action could not be sustained directly under s 27, but the Commission elected not to pursue this alternative line of argument. 
Brown and Gilbert JJ concurring) the Court of Appeal found in the Commission's favour on all counts. This included a finding that the understanding reached by the representatives of the real estate agencies at the 30 September meeting engaged the s 30 deeming provisions of the Commerce Act. This Part critically examines the Court of Appeal's finding on this crucial point. ${ }^{33}$

With respect, it is difficult to support the Court of Appeal's position on this point, at least on the basis of the Court's stated reasons. Whether or not s 30 is engaged in respect of an arrangement or understanding that does not directly implicate final output prices is a conceptually difficult issue to tackle. It is to be anticipated that the issue would be subjected to detailed consideration and rigorous analysis by any reviewing court. However, the Court seemed to deliberately eschew close scrutiny of the conceptual, practical and factual issues in play. Instead it elected to resolve the point on the basis of rather sparse reasoning that turned on rhetorical appeals to matters that must "obviously" or "plainly" be the case. For example: "[p] lainly the agreement in principle to withdraw from agency-paid advertising would affect price"; 34 and "[o]bviously the starting position of any vendor as to price will have some effect on the ultimate agreement on price. This is all that is required." 35 Also: 36

We conclude that the Judge erred in finding that the agencies gave effect to the arrangement or understanding by withdrawing the listing and moving to vendor funding, but that this did not have the purpose of fixing the price or elements of it. Plainly an agreement in principle along these lines would have that purpose.

The result is that the required link between the alleged understanding in respect of input costs and intended or actual effects on final output prices is assumed rather than demonstrated in the Court's analysis.

Although it is somewhat unclear, the specific finding of the Court appears to be that the real estate agencies' arrangement had the purpose of constraining discretion over final output prices. ${ }^{37}$ Actual pricing effects were therefore not the predominant focus of the Court's inquiry. The Court lent on both purpose and likely effect as the basis for its finding at times and even appears to conflate the two

33 There are of course many other interesting conceptual and legal issues arising from the judgment, such as whether there was sufficient mutuality among the parties to constitute an arrangement or whether fixing a component of a final price is sufficient to trigger liability under s 30. For useful discussion of these points see John Land "Price fixing without fixing the whole price" (2019) 295 LawTalk 48.

34 Lodge (CA), above n 1, at [89] (emphasis added).

35 At [90] (emphasis added).

36 At [93] (emphasis added).

37 At [93]. 
concepts at one point. ${ }^{38}$ Regardless, the Court was clear that it was adopting an objective test to the issues in play, rather than being concerned with the subjective intentions of the parties to the arrangement. ${ }^{39}$ This is all perfectly consistent with standard competition law analysis; as an objective concept, purpose (in particular) allows a court to identify prohibited conduct with reference to the nature of the arrangement directly. However, it is equally clear that cogent legal and economic analysis is required to determine if per se liability applies, which informs when and how purpose as an objective concept can be relied on. ${ }^{40} \mathrm{~A}$ finding of a purpose or likely effect must therefore rely on a plausible inference that the alleged arrangement is at least capable of influencing final prices. This is precisely what the High Court found not to be the case and represented the conceptual barrier that the Court of Appeal was required to overcome in order to establish per se liability.

This Part advances three distinct but related criticisms of the Court's approach to this issue. The first criticism is that the Court misapplied the overseas case law. None of the overseas cases cited by the Court to support its analysis are analogous to the underlying factual or legal context at issue in Lodge, and all turned on detailed factual analysis rather than crude assumptions as to pricing effects. The second criticism is that that failure to engage in close factual analysis led the Court to misinterpret important factual findings made by the High Court at first instance. While the Court of Appeal understood the impugned arrangement as one involving a co-ordinated practice subject to a residual discretion, the High Court was clear that the arrangement was so open-ended as to amount to no coordination at all. The third criticism involves broader matters of legal interpretation and policy considerations. It is contended that the Court of Appeal's judgment extends per se liability beyond clear statutory boundaries that have been deliberately set, with the inevitable result of an erosion of legal certainty and important evidentiary protections. In light of these three criticisms there is good reason to doubt whether the Court of Appeal's decision in Lodge can credibly stand.

It is important to make clear that these criticisms relate primarily to the Court's mode of analysis, not the final result in the case. It was perfectly open to the Court to make a finding that the alleged arrangement among the real estate agencies amounted to price fixing in breach of $s 30$, provided that there was at least some probative factual evidence to support that claim. This article does not offer a view of the merits of the defendant's conduct one way or another. It does insist, however, that liability under competition law prohibitions ought to be demonstrated rather than simply assumed.

38 At [87].

39 At [35], citing Giltrap City Ltd v Commerce Commission [2004] 1 NZLR 608 (CA) at [73].

40 See Chris Noonan "Slaughterhouse Rules: The Purpose of a Provision in the Commerce Act 1986" (2013) 19 NZBLQ 305 at 311. 


\section{A Case Law}

The Court of Appeal recognised that the alleged arrangement among the real estate agencies left open a degree of uncertainty as to treatment of Trade Me listing fees. ${ }^{41}$ However, the Court determined that close assessment of the precise nature and extent of any uncertainty was legally irrelevant, and pointed to a number of overseas cases in support of its view. In reliance on this overseas case law, the Court concluded that the existence of any residual uncertainty could not save the arrangement from coming within the terms of s 30. However, none of the overseas cases relied on actually provide support for the Court's position on this issue.

The first relevant case is Dole Food Company Inc v European Commission, ${ }^{42}$ relied on by the Court for the proposition that arrangements relating to initial quotes (or opening offers to the market) interfere with the competitive setting of final market prices even though these initial quotes do not establish an absolute position in respect of final prices. ${ }^{43}$ Broadly, the reasoning in Dole Food Company is as follows. An arrangement among competitors determined initial quoting procedures. The Court found that this interfered with final prices because the arrangement effectively set key parameters regarding how those final prices would be arrived at.

At first glance this may indeed be taken to superficially support the Court of Appeal's position that any indirect influence over how final prices are arrived at constitutes price fixing. However, Dole Food Company is not a case which establishes a general proposition of law in these broad terms, and is instead factually contingent. The General Court (European Union) found that an exchange of information such as quote prices must be regarded as pursuing an anti-competitive object only if that exchange of information is capable of removing uncertainty between participants as regards the timing, extent, and details of the modifications to be adopted by the operator concerned in their conduct on the market. ${ }^{44}$ As the Dole Food Company judgment makes abundantly clear, this is something that needs to be demonstrated on the facts rather than simply assumed.

And, of course, that is precisely what the extensive evidence before the General Court in Dole Food Company demonstrated. The European Commission only brought proceedings in the case because it had extensively examined the content, frequency and duration of the communications among the competitors in the case, and the wider legal and economic context. All of these pieces of evidence were available to the General Court to assist with its assessment of the issues. ${ }^{45}$ Through this detailed evidence, the prosecuting Commission was able to show to the Court's satisfaction that

41 The degree and nature of that discretion is itself an important question and is examined below.

42 Case T-588/08 Dole Food Company Inc v European Commission ECLI:EU:T:2013:130.

43 Lodge (CA), above n 1, at [83].

44 Dole Food Company, above n 42, at [121]-[122].

45 At [78]. 
the intent and effect was to influence final output prices. There was even specific evidence presented that the terms of certain contracts set actual prices subject to a formula where initial quotation prices were a key variable. ${ }^{46}$ The arrangement therefore resulted in unmediated interference with output prices and so there was direct evidence that interference with final prices was the general purpose of the alleged co-ordination. There was simply no evidence of a similar purpose to control output prices in the Lodge case, nor any evidence of a direct effect on output prices. It is difficult to see how Dole Food Company could be relied on in support of the Court of Appeal's analysis.

Further, Dole Food Company has been identified as something of an outlier in European competition law practice. Expert commentary has read down the effect of the case in respect of the application of per se liability, with one publication stating that a rule that "any reduction in uncertainty is an infringement by object [that is, is a per se offence]" is "likely to read too much into the judgment". ${ }^{47}$ It is therefore surprising that this is precisely the proposition that the Court of Appeal relied on Dole Food Company for. Properly understood, Dole Food Company actually stands for a more limited - but still vitally important - proposition, that "an exchange of parameters relevant for future pricing, between people involved in price-setting, is presumed to restrict competition". ${ }^{48}$ The factual point that the information exchange (or arrangement) relates to future pricing parameters must be demonstrated, otherwise any offence is unlikely to be per se in nature.

The Court of Appeal in Lodge also drew some support from the related British case of Balmoral Tanks Ltd $v$ Competition and Markets Authority, ${ }^{49}$ which discussed the Dole Foods Company judgment. While it does not appear that the Court of Appeal placed any great weight on Balmoral Tanks itself, it is important to note that Balmoral Tanks also concerned an exchange of current and future pricing information. As a result, the subject matter of the relevant arrangement in that case also related directly to the final prices being offered in the market. It does not serve as precedent for how and when discussions on cost information affect price.

The third relevant case referred to in the Court of Appeal's judgment in Lodge is Australian Competition and Consumer Commission v CC (NSW) Pty Ltd. ${ }^{50}$ The facts in this Australian case are so far removed from the issues in Lodge that it is bemusing that it should have such a prominent place in the judgment. CC (NSW) concerned an arrangement among competitors where the winner of a tender would pay a fee of $\$ 750,000$ to each of the unsuccessful tenders. While this behaviour is clearly pernicious according to standard competition law principles, the Court was careful to point out that

46 At [13].

47 Kristian Hugmark and My Becher "Dole v Commission: Exchange of Information, Between Competitors, on Price-Related Parameters" (2015) 6 JECL \& Pract 652 at 653.

48 At 653 .

49 Balmoral Tanks Ltd v Competition and Markets Authority [2017] CAT 23.

50 CC (NSW), above n 25. 
key factual questions needed to be demonstrated on the evidence before liability would follow. One of those key factual questions was that any understanding between the competitors in relation to tenders would have the effect of controlling prices. ${ }^{51}$ Indeed, the Court then painstakingly examined the evidential record before drawing any firm conclusions. Critically for the purposes of our current analysis, the facts of the case did indeed show not just that this arrangement existed, but that the fee for unsuccessful tenderers was loaded into final bid pricing. ${ }^{52}$ Like Dole Foods Company, CC (NSW) therefore also concerns a direct impact on final prices which could be demonstrated on the factual evidence rather than inferred from nebulous assumptions, and per se liability followed on that basis. Any support in the case for the Court of Appeal's approach in Lodge is therefore tenuous.

The reliance of the Court of Appeal in Lodge on CC (NSW) case is all the more perplexing given the legal framework that was found to apply in the latter case. As a matter of law, the Court in $C C$ (NSW) found that controlling merely a component of the final output price was not sufficient to establish legal liability: ${ }^{53}$

As I have already indicated, in my view it is not enough for the Commission to establish, as it has pleaded, that the ... [understanding among the competitors] was likely to have the effect of controlling a component of the price: it must establish that it was likely to have the effect of controlling the overall price.

The claim here is not that s 30 does not address itself to individual pricing components as well as the overall price, as there is sound domestic case law already on this point. ${ }^{54}$ But to rely on CC (NSW) to support a conclusion that treatment of an input cost must necessarily impact on final prices is to go well beyond the reasoning of the Court in that case. This should at least have given reason to pause and reflect on the utility of $C C$ (NSW) in the context of Lodge before it was relied on as influential precedent.

The final overseas case of relevance is a reference to Plymouth Dealers' Association of Northern California $v$ United States. ${ }^{55}$ The Court in Lodge appears to rely on this case to support the proposition that an arrangement regarding an initial position will affect prices in an anti-competitive way even if final prices are still to be negotiated. In Plymouth Dealers' Association, certain car dealership competitors circulated among themselves a suggested price list for various models of cars on their lots. The Court of Appeal in Lodge drew particular inspiration from this passage: ${ }^{56}$

\author{
51 At [177]. \\ 52 At [184]-[199]. \\ 53 At [184]. \\ 54 Commerce Commission v Caltex New Zealand Ltd [1998] 2 NZLR 78 (HC). \\ 55 Plymouth Dealers' Association of Northern California v United States 279 F 2d 128 (9th Cir 1960). \\ 56 At 132, as cited in Lodge (CA), above n 1, at [85].
}


The test is not what the actual effect is on prices, but whether such agreements interfere with "the freedom of traders and thereby restrain their ability to sell in accordance with their own judgment" ... The competition between the Plymouth dealers and the fact that the dealers used the fixed uniform list price in most instances only as a starting point, is of no consequence. It was an agreed starting point; it had been agreed upon between competitors; it was in some instances in the record respected and followed; it had to do with, and had its effect upon, price.

It is important to read this passage against the understanding that the key issue for the Court was whether the offence should be tried as a per se violation of the Sherman Act. ${ }^{57}$ As in Europe, the distinction between per se offences and the need for rule of reason analysis is a feature of the case law, not a statutory imperative. As a result, the precise answer to the type of question motivating the Court in Plymouth Dealers' Association is of limited relevance in New Zealand where the distinction is enshrined in statute and explicitly tied to pricing effects. This may appear to be labouring the point, but when the difference in legal framework is properly understood the passage from Plymouth Dealers' Association cited by the Court of Appeal can be seen to be describing the legal implications of finding that a per se offence has been committed. It does not establish a test for whether a per se offence has occurred, nor does it support the proposition that residual uncertainty as to the end price of goods or services is irrelevant to the existence of a per se offence.

This points to a broader conceptual issue with a New Zealand court drawing on cases from overseas jurisdictions like the United States and Europe when addressing s 30's per se effect. The statutory provisions dealing with co-ordinated conduct in other major jurisdictions do not bifurcate effects analysis and per se offences in the same way as the Commerce Act. Co-ordinated conduct is usually prohibited on the express basis that it interferes with the competitive market dynamic. ${ }^{58}$ While this usually implies that effects-based analysis needs to be undertaken, case law has developed specific per se offences where the societal benefit from the conduct is not obvious. This includes the standard examples of price fixing, market allocation and output restrictions. As a result, much of the overseas case law that might appear relevant to the Lodge case is actually concerned with the consequences of bringing conduct within judicially created per se offences. It is difficult to extract general principles from this case law context that might demonstrate that certain conduct indirectly impacts prices in a way that engages statutory deeming provisions such as s 30 of the Commerce Act, as that is simply not a question that is relevant in these other jurisdictions.

It is unclear on the face of the Court of Appeal's judgment whether it appreciated this important distinction. Nevertheless, the Court of Appeal in Lodge put significant weight on these specific facts

57 Sherman Antitrust Act of 189015 USC § 1 (US).

58 For example Treaty on the Functioning of the European Union [2016] OJ C202/1, art 101; and Sherman Antitrust Act of $1890 \S 1$ (US). 
of those cases, drawing a direct analogy between the facts of Lodge and Plymouth Dealers' Association: ${ }^{59}$

[88] By way of example, if retailers of motor vehicles in a street all agreed on an asking price for a certain model, aware that this was the asking price only and the end price after negotiation could be quite different, that would have anti-competitive effect in the way discussed in Plymouth Dealers' Association. The starting point for one side of a negotiation about price would undoubtedly affect the end price, even if it may be possible or even likely the end price would be different from the starting point.

[89] So here the understanding was of a starting point of vendor funding, while recognising that there would be occasions on which the agency may choose to fund ...

However, the decision in Plymouth Dealers' Association turned on more than the existence of the price list itself. There was evidence that the use of the list impacted directly on final prices, including that the list was set particularly high so that "the ultimate percentage of gross profit over the factory price could be higher", ${ }^{60}$ and that "testimony by members of the Association from which it can be inferred that some sales actually were made at the list price". ${ }^{61}$ These factual findings were essential for the Court to find that the exchange of the price list fell into the category of price-fixing and so could be treated as a per se offence. This reliance on the factual evidence stands in contrast to the supposition and implication that drove the Court's analysis in Lodge.

Overall, the case law cited by the Court of Appeal in Lodge does little to support the key propositions on which the Court made its finding of liability under s 30. According to these cases, detailed factual inquiry is an essential component of establishing per se liability, and so the nature and extent of any residual uncertainty when determining final prices is critically important. The Court of Appeal, however, relied on these cases as support for precisely the opposite proposition.

\section{B Factual Analysis}

On the misplaced strength of the overseas case law, the Court of Appeal was comfortable to proceed without close analysis of the underlying facts of the case. In contrast to the careful consideration of the underlying facts on display in the High Court judgment, the Court of Appeal went so far as to state that it saw no reason to examine all of the available evidence. ${ }^{62}$ There was no need to demonstrate that the arrangement had, or would be likely to have, any actual, tangible effect on the process for setting prices for real estate services, and indeed the judgment is notable for its absence of any such evidence. Assumption and supposition as to the effect of the arrangement on final output

59 Lodge (CA), above n 1.

60 Plymouth Dealers' Association, above n 55, at 133.

61 At 133

62 Lodge (CA), above n 1, at [79]. 
prices was a sufficient foundation to establish liability under s 30 in the Court's view. Given the nature of the arrangement and its focus on input costs, the result for the Court was simply obvious.

Aside from the point demonstrated in the previous section that an analysis of the actual price effects (or an actual intention to achieve price effects) of impugned behaviour is standard practice in competition law cases, the Court's willingness to eschew close consideration of the factual evidence is concerning for a further reason. That reason is that close analysis of factual evidence is important in that it provides useful context for understanding and defending the High Court's decision on this issue. The Court expressed some confusion as to the approach taken in the High Court. ${ }^{63}$ In particular, it was apparently unclear to the Court of Appeal whether Jagose $J$ treated funding by an individual agent, rather than by the vendor, as falling within the vendor funding model or representing a possible departure from that model. The Court of Appeal preferred the interpretation that funding by an individual agent came within vendor funding, ${ }^{64}$ and so the range of options available to an agency outside of vendor funding was diminished. This was an important finding for the Court of Appeal, because it framed the issue in terms of an agreed default approach to the treatment of input costs subject to residual discretion. Including individual agent funding within the vendor funding arrangement expands the scope of the default arrangement and reduces the scope of possible departures from that default arrangement. In fact, the only permissible departure from vendor funding under the arrangement was for the agency to pay part or all of the Trade Me listing fee. Framing the issue in these terms allowed the Court to effectively dismiss any consideration of the limited residual discretion on the part of the agency that it found to exist. ${ }^{65}$

However, this line of reasoning seems to be based on a profound misunderstanding of the factual context as set out in the High Court's decision. As outlined above, Jagose $\mathrm{J}$ found that "vendor funding" had a particular and rather benign meaning - that no real estate agency would self-fund all of its respective Trade Me listing fees going forward. ${ }^{66}$ The respective agencies might have equally agreed that funding of Trade Me listing fees would be determined by the market on a case-by-case basis, or simply that there would be no standard practice in respect of Trade Me listing fees for future transactions. Such was the open-textured nature of the term "vendor funding" that it essentially included all possible pricing options in respect of each individual transaction with a vendor, be it agency funding, agent funding, direct vendor funding, or any combination of those funding sources. This factual context was critical to the High Court's finding that the alleged arrangement could have no plausible effect on final output prices.

\author{
63 At [22]. \\ 64 At [23]. \\ 65 At [78]. \\ 66 Lodge (HC), above n 4, at [227].
}


When the terms of the arrangement are understood in this way, it is far from "plain" or "obvious" that the arrangement would have any effect on final output prices. It is only the misunderstanding that vendor funding implied a necessary commitment to push costs onto vendors directly in the first instance that makes flow-on pricing effects at all relevant. This misunderstanding also helps to explain why the Court of Appeal found Jagose J's judgment to be confusing and perhaps contradictory. As set out above, the High Court's statement that the listing fees would "in principle" be paid by the vendor meant simply that the usual industry practice was that third party costs were invoiced separately to the vendor. ${ }^{67}$ It did not mean that direct vendor funding was an agreed starting position for further negotiation. As a result, the factual issue at the heart of the case was whether the alleged arrangement constituted any kind of meaningful constraint on pricing at all, not whether the presence of residual discretion invalidated a co-ordinated pricing strategy. Failing to appreciate this careful finding of fact made by the High Court changed the legal test and the nature of the analysis when the issues were before the Court of Appeal. The result was that liability under s 30 could only be established on the basis of a crude facsimile of actual arrangement apparently established by the defendants.

\section{Policy Considerations}

The final strand of the Court of Appeal's approach justifying its "once over lightly" analysis appears to be a policy concern that sustained consideration of the motiving facts would deprive s 30 of its intended effect. A statutory provision establishing per se liability would see its underlying purpose frustrated if the courts were to entertain argument based on the factual evidence. For example, this policy consideration appears to be part of the rationale behind the following passage: ${ }^{68}$

In reality arrangements and understandings not amounting to a contract will generally be poorly defined. There are few cases where anti-competitive behaviour is clearly documented, or indeed of precise articulation. Often, because an agreement or understanding will not be a contract, there will be room for parties to exercise discretion. All that is needed is an arrangement or understanding that will be likely to interfere with the competitive setting of price. That understanding does not need to be precise and to cover all possible eventualities, or indeed relate directly to the ultimate price. If an understood ability to depart from the agreement or understanding was fatal to the application of s 30, then the application of s 30 could be easily avoided by the provision of some reserved right of departure. That would be contrary to the purpose of s 30 .

There are, however, important reasons of law and policy that suggest the Court's approach to this issue should be revisited.

The key legal reason that counts against the Court's analysis on this point is that the express language of s 30 itself seems to require close factual analysis where the conceptual link between the

67 See Lodge (HC), above n 4, at [215].

68 Lodge (CA), above n 1, at [91]. 
arrangement and (intended) pricing effects is not direct. The statutory test for liability under s 30 is that the arrangement "has the purpose, or has or is likely to have the effect" of controlling prices. The language of the section therefore indicates that an assessment of the (likely) effects on final output prices is essential to the inquiry. If prices are not implicated in some way, there is no necessary transfer of wealth from consumers to cartelists, so the assumption of harm is misplaced. The drafting of s 30 appears to expressly recognise that fact. Cogent inquiry into alleged pricing effects where these are not obvious therefore goes to the heart of whether the conduct is in fact "hard core" cartel activity that warrants the application of blunt, over deterring per se liability. This is the policy rationale a court is required to use to justify any extension of s 30's scope beyond its plain language, yet the Court of Appeal assiduously avoids doing so.

Of course, a deeming provision such as s 30 is intended to avoid extensive and complex inquiry into market dynamics, ${ }^{69}$ a field in which the courts are not experts. Engaging in this type of analysis of in-market effects on competition would certainly be contrary to s 30's core function within the scheme of the Commerce Act. A degree of arbitrariness and over deterrence is an accepted feature of all per se offences, and there is no intention here to challenge this reality. Unfortunately, the Court of Appeal appears to have conflated analysis of market effects and competitive tension with the need to establish a factual link between any alleged arrangement and consequent pricing effects when framing the provision's purpose and effect. Whether any residual discretion impacts on the free ability to set prices is directly relevant to whether or not $\mathrm{s} 30$ is engaged. Undertaking this analysis does not deprive s 30 of its relevance, but ensures that the legally prescribed parameters within which market effects cannot impact on the Court's analysis are maintained.

In Lodge the Court of Appeal has effectively extended the scope of liability under s 30 to situations where the link between a competitors' arrangement and a purpose or (likely) effect on final prices is unclear without a firm statutory basis for doing so. This gives rise to significant policy concerns with the approach taken by the Court. Per se liability is a blunt legal tool that places defendants in a uniquely vulnerable position. The protection of an evidential burden to establish liability is effectively removed, and as a result where per se liability is invoked the defendant will usually lose. ${ }^{70}$ While this can be justified given the clear harm of co-ordinated behaviour that affects pricing outcomes, the policy grounds for a similar legal effect where no link to pricing effects can be established is not nearly as discernible. No credible theory of economic harm motivates prosecution in such cases, and there is a risk that this undermines the lucidity of the competition law framework concerning statutory obligations and prohibitions that future courts, businesses and their advisors must apply.

69 See for example Northern Pacific Railway v United States 396 US 1 (1958) at 5; and United States v Topco Associates Inc 405 US 596 (1972) at 609-610.

70 Scott, above n 14, at 203. 
This final point is particularly apposite: that certainty is generally understood to be a key objective of the application and development of New Zealand's competition law framework. Where the application of competition law is consistent and predictable, market participants are able to engage in commercial conduct and arrange their business affairs with confidence that they are not in breach of the law. Where per se liability is extended beyond the boundaries of the express statutory language, however, the law becomes significantly less certain. In what circumstances precisely will a deciding court consider that an impact on final prices is sufficiently "plain" or "obvious" if there is no factual analysis of pricing effects to guide decision-making? Businesses in New Zealand now face this considerable uncertainty, and must choose between foregoing economically beneficial behaviour or risking prosecution under a competition law standard where there may be no effective defence. This undesirable outcome could have been avoided if the Court had based any finding of liability on close factual analysis.

\section{CONCLUSIONS}

In this article, it has been argued that the methodology adopted by the Court of Appeal in Lodge is fundamentally flawed and cannot serve as a credible basis for a finding of liability under s 30 of the Commerce Act. When subjected to examination against the overseas case law, the quality of the factual analysis and consistency with important legal and policy considerations, the Court of Appeal judgment comes up short. The Court of Appeal relied to an extraordinary extent on intuition, supposition and assumption in respect of critical points where close factual analysis, appreciation of context and careful reasoning were required. This flawed approach stands in contrast to the careful factual analysis undertaken by the High Court in the same case, and ultimately the judgment of Jagose $\mathrm{J}$ is to be preferred.

Placing Lodge and the ramifications of the Court of Appeal's judgment in a broader context, in this respect it is relevant to note that since the events that gave rise to the Court of Appeal's decision in Lodge, s 30 of the Commerce Act has been repealed and replaced. However, the trigger for per se liability under the new provisions is still expressed in terms of "purpose, effect or likely effect" of controlling prices. ${ }^{71}$ Despite this similarity, it is to be hoped that any future court applying those new provisions takes every opportunity to distinguish Lodge so that it does not function as a controlling precedent in respect of the scope of the new provisions.

The issue of the circumstances in which per se liability attaches is of particular moment given the strong likelihood that per se conduct will soon be subject to criminal sanctions. ${ }^{72}$ If reform of this nature eventuates it will raise the stakes for defendants immensely, and confidence in the efficacy and legitimacy of competition law standards will be essential. Criminal law is understood to be a final resort, and so it should be applied deliberately rather than as a result of an accident of interpretation.

71 Commerce Act, s 30A(1).

72 Commerce (Criminalisation of Cartels) Amendment Bill. 
In contrast to the easing of the burden on the prosecution that results from the Lodge decision, the burden for imposing criminal liability ought to be high and fall squarely on those alleging breach of the law. ${ }^{73}$ In the context of s 30's per se liability, this burden includes justifying that the impugned conduct is worthy of the opprobrium of the criminal justice system. If per se liability is able to be invoked while avoiding detailed consideration of whether the statutory terms of liability are actually satisfied, then this confidence is likely to be lacking. Insisting that the Commission, as prosecutor, actually demonstrate its case to the usual evidential standard is key to maintaining appropriate protections for defendants from undesirable prosecutions. The Court of Appeal's decision in Lodge sits uncomfortably with this new reality.

Further developments may be able to address these issues. The Supreme Court has recently granted to the defendants leave to appeal on the question of the proper application of s 30 as well as other issues. It is to be hoped that when the Supreme Court considers the substantive arguments in the case the Court of Appeal judgment stands as a warning of the pitfalls of eschewing close analysis of the underlying facts. The principled and lawful application of competition law is often highly contingent on the underlying facts. Section 30 intentionally incorporates a requirement of analysis of pricing effects, and considered analysis of this issue ought to form the basis of any Supreme Court opinion regardless of whether liability under s 30 is established or dismissed.

Ultimately, the legacy of Lodge is likely to be a broader lesson for the New Zealand competition law courts that there is often no avoiding close analysis of the underlying facts in the context of their economic effects and governing law. Competition law is complex and exacting, and attempts to develop heuristics or shortcuts can hinder and obscure as much as they assist and clarify efforts to locate the right answer. Indeed, the integrity of its factual analysis is often all a court may have to justify a finding to extend or confine the scope of per se liability, a finding that has serious consequences for all parties involved as well as the proper operation of the New Zealand economy.

73 Douglas Husak Overcriminalization: The Limits of the Criminal Law (Oxford University Press, Oxford, 2007) at 100. 